\title{
Analysis of The Budget Planning Process and Budget Execution Process
}

\author{
Mia Alfin Dahana, Ermawati
}

\begin{abstract}
This study aims to analyse the process of budgeting planning and budget execution. This research was conducted by the Service of the Empowerment and Protection of Children and Population Control (DPPAPP) of the DKI Jakarta Province. The method used in this research is qualitative with an ethnomethodology approach. The result of this study is that the process of planning and implementing the budget carried out by the DPPAPP, in accordance with existing procedures and regulations. However, although it has been carried out in accordance with procedures and regulations, which are fixed, there is still a suboptimal absorption of the budget, which occurs due to internal factors and external factors. The internal factors consist of human resources, while external factors consist of the auction process and regulatory changes. It is hoped that the DPPAPP can increase the competence of the human resources it possesses, especially with regards to the budget planning process and the budget execution process. These processes can be done through socializations for the human resources, with regards to the budget planning process and the budget execution process, in order to minimalize inconsistencies between budget planning and budget execution in the future. Aside from that, in order to mitigate the external factors, each work unit must identify issues that may to arise in the next budget execution.
\end{abstract}

Keywords-Budget planning process, budget execution process, budget absorption.

\section{INTRODUCTION}

The development of regional autonomy currently requires Local Government Agencies (SKPD) to improve the quality of public services for the people. SKPD can comprise of Bodies, Services, Offices, and other units. The SKPD is a management instrument in regional development, that is led by the head of the SKPD. The SKPD is tasked in providing public services to the people. Aside from providing services, the people also demand transparency and public accountability.

The Service of the Empowerment and Protection of Children and Population Control (DPPAPP) is an SKPD that has the task of implementing people empowerment, women empowerment and child protection, population control, and planned parenthood, as well as promoting family resilience. These goals can be reached through the implementation of programs, as well as work plans that have been drafted. In the implementation of local governance, the planning and budgeting are crucial processes. This is due to the fact of its correlation with the welfare of the people. Local governments must execute planning according to the process, starting from the formulation of the Long-Term Local Development Plan

Published on July 22, 2020

Mia Alfin Dahana, Universitas Pembangunan Nasional Veteran Jakarta, Indonesia.

(email: miaalfin92@gmail.com)
(RPJPD) for a period of five years, which takes into account the Mid-Term National Development Plan (RPJMN). After the RPJPD is set, local governments formulate their Regional Government Work Plan Pemerintah (RKPD), which is the elaboration of the RPJMD for a period of one year, which refers to the Government Work Plan.

Planning and budgeting are regulated in Law Number 25 Year 2004, and Law Number 17 Year 2003. Based on these laws, budgets that have already been set should be absorbed by local governments. According to the Directorate General of Financial Balance (DJPK), the planning process has a significant influence on the rate of local expenditure absorption in funding public service activities. Planning is one of the most important elements in the local government level, and can aggravate all other obstacles in the budget absorption process.

The budget execution process is a phase that must be implemented after the budget planning process. The budget planning process is an effort done to realize all policies and plans that have been set [11]. The process of budget execution comprises of internal issues of a work unit, and also processes from payment procedures. These two items affect the rate of budget absorption.

The DPPAPP is one of the SKPDs in DKI Jakarta. It comprises of several departments, such as: Population Control of Planned Parenthood, People Empowerment, Protection of Women and Children, PK2, Violence Towards Women and Child Protection. During the research process, the researcher found several obstacles related to the budget absorption in the DPPAP in the DKI Jakarta Province. The researched found that in the LKIP in 2019, there were activities whose budget realization was not according to target, or still low. These activities were activities executed by the department of Protection of Women and Children (PPA).

The table shows that the activity of Planning Guidance and Gender Responsive Budgeting (PPRG) in government instruments, along with the OPD driver, only has a realization of $63.24 \%$ or Rp. 55.260.000, from the budget target of Rp. 87.380.000. This low rate of financial realization in this activity is caused due to the fact that the activity was initially planned to be executed in three meetings, but was only realized for two meetings. Meanwhile, in the activity of Improving Institutional Network of Women and Children regarding the Quality of Life of Women and Children, had a realization of only $64.74 \%$. The result of the observation indicate that the process of planning and budgeting or the execution process was not implemented effectively, which 
resulted in inconsistencies between the planning and the execution of the budget.

To achieve targeted budget absorption, there needs to be consistency between the planning and the execution of the budget. There are many factors that become the cause of inconsistency between the planning and the execution of the budget. A not well-planned planning process will have an impact on the implementation of the work program. Likewise, if the execution of the activity is not in accordance with the plan that has been formulated, it can affect the target of the realization of the budget that has been set.

\section{LITERATURE REVIEW}

\section{A. Agency Theory}

The agency theory is a theory that explains the relationship between the principal and the agent. Jensen and Meckling [16] stated that the agency relationship is a contract between the principal and the agent, viewing the delegation of several decision-making authorities to the agent. Lupia and Mccubbins [20] explain that the delegation occurs when a person or a group of persons (the principal), chooses another person or a group of persons (the agent) to act in accordance with the interests of the principal.

This theory emerged due to the relationship between the agent and the principal. The agent has been contracted to deliver specific tasks by the principal. The principal must provide a reward to the agent for the service that the agent has provided. When a conflict of interest arises, it presents an agency problem.

\section{B. Budgeting Planning}

The term 'budgeting planning' may be defined separately. First, 'planning' may be defined as a process to determine the right future action, through order of choice, in consideration of available resources. Second, 'budgeting' can be defined as a process to draft a budget, in which the local budget (APBD) can be defined as the yearly financial plan of local governments that have been discussed and agreed upon by the local government and the Local House of Representatives (DPRD), and ratifies through regional laws. According to [9], planning is an inseparable unit from the process of organization management. Meanwhile, budgeting is the process or method of preparing a budget.

In public sector organizations, budgeting is part of the political process. Public sector budgeting is related to the process of determining the amount of funds allocated to each program and activity. In conducting planning, there needs to be a division of the budget according to each activity that will be executed. A study conducted by [3] states that in planning, one must pay attention to fund allocation, in which funds must be allocated accordingly.

The system of national development has been regulated in Law Number 25 Year 2004. This law acts as the basis for each institution to draft the budget, revenue, and also local expenditure. Despite the fact that the ratification of the budget must be informed and influenced by strategic organizational priorities, it is now always done accordingly, and therefore the process of budget ratification often times effectively disconnects from the strategy [31].

\section{Government Budget Procedure}

Law Number 25 Year 2004 is the basis for each institution to draft the revenue budget as well as the local expenditure. The process of budget drafting requires all elements to be in synergy, in order to result in a budget plan that is accurate and in line, especially in SKPDs, which require all departments to partake in the process of budget drafting. This is according to a study conducted by [7], which stated that it is best that all departments partake in the budget plan drafting process. Similarly, a study conducted by [19] stated that the budget drafting process must follow regulations that apply, in which these regulations should act as a guide in the process of the drafting of the local government budget (APBD).

In the process of budget drafting, one of the obstacles faced is the lack of quality in human resources, and the lack of internal coordination between departments withing the SKPD. This is supported by a study conducted by [17], which stated that the hampering factors in the process of budget planning are the difficulties faced, which are the difficulties in executing coordination between departments, and the inability to identify the problems currently faced. External factors also have a significant role in the process of budget planning, according to Pilcher and Perrin [2] in their study, which showed a political indication during the process of planning, which would affect accountability. Based on these explanations, it can be concluded that both internal and external factors can affect the budget planning process. Adequate human resources, good internal coordination, evaluation towards risks that may be faced, and also political factors, or changes in the government's regulations itself, are essential to ensure proper budget planning. The lack of these factors may affect the DPPAPP in implementing their budget procedure.

\section{Budget Implementation/Treasury}

Oman [28] explained that the National Budget (APBN) in the central government begins with the publishing of the Budget Implementation List (DIPA). Upon the start of a budget period, the DIPA must quickly be published to be distributed to work units as the budget users in ministries/institutions. In local governments, upon the publishing of Local Regulations regarding the APBD, the SKPD must draft a Budget Implementation Document (DPA). In local governments, the Fund Provision Letter (SPD), a document that states the availability of funds to execute an activity, is still required.

According to [21], in the budget execution phase, the most important item that must be considered by public financial managers, is to have an accounting system, and a management control system. Public financial managers are responsible to create adequate accounting systems that can be relied on for the process of budget drafting for the next period. A good accounting system also calls for the creation of an adequate internal control system.

\section{E. Budget Absorption}

Noviwijaya and Rohman [27] states that budget absorption of a work unit is the proportion of a work unit's budget that has been realization within one budget year. Generally, the people can comprehend this more easily as the disbursement 
of the budget. How the budget that has been drafted will be used or disbursed.

Although a low budget absorption is not the only indicator to assess the success of financial performance in local governments, the local governments must still focus their attention on this. If low budget absorption persists, it can be assured that performance targets that have been set are not reached, which means that there are dormant funds in the local government that can be used to invest in more productive places [11].

The condition of low and unproportioned budget absorption, according to [24] has implications toward:

a. The slowdown of government activities/programs execution, which affects public services.

b. The postponed disbursement of funds for goods/services expenditure, which causes the fiscal stimulus function and multiplier effect from the government expenditure towards economic activities in the community to not become optimal at the start of the budget year.

c. The cumulation of bills towards the State at the end of the budget year, which causes significant burden towards the provision of government money/cash, which can cause cash mismatch.

\section{RESEARCH Methodology}

This study uses the qualitative research method. Moleong [25] expressed that qualitative research is a research aimed to understand phenomenon about what is experienced by the research subject, such as behavior, perception, motivation, actions, etc., holidtically, and through descriptions using words and language, in a specific scientific concept, and makes use of several scientific methods. Generally, according to [12], [23], qualitative research seeks in-depth understanding on the research phenomenon that involves humans and social interpretation, experience, and actions [12]. This study uses the ethnomethodology approach. This means that the researcher starts by exploring the processes of planning and budget execution, in increasing budget realization or budget absorption, and to determine the causes of activities that have a low budget absorption that is under the set target, as the problem that is studied. Kamayanti [18] states that ethnomethodology refers to how and why an activity is executed by someone. Similarly, Ahmadi [1] argues that ethnomethodology focuses more on the cores of the investigated issue, which is a method used by one to understand the situation in which they are in.

This study uses two data sources: primary data, and secondary data. The primary data used is the result of interviews with informants in the finance department that are in charge of planning. The secondary data used are the Document of Budget Change Implementation, Activity Report of Governmental Institutions, the Work Plan Document, and the budget of the DPPAPP. Efferin [14] states that the data collection method is a bridge that will connect the researcher with the social phenomenon that they study. Through the method chosen, the researcher collects various data to answer the existing problems. Qualitative research has several data collection methods, which are: observation, interview, and document analysis. The collection method used in this study uses interviews, observation, and documentation.

\section{RESUlts AND DisCUSSION}

\section{A. Budget Planning}

Planning is a highly important process that needs to be routinely done by every SKPD before executing its activities for every period. To draft the financial budget, the DPPAPP has its own sources or legal basis that currently apply. The first step is formulating the strategic plan for a time period of five years, and then elaborating it into an annual performance plan. The performance plan is a strategic document whose main purpose is to identify indicator of performance and target for every goal, set based on rules that the government has set [22]. After the departments have drafted and discussed internally, it will be discussed with all bodies within the DPPAPP, which constitutes: head of service, subs ector of planning and subsector of finance. The result of this study is in line with the research conducted by [34] which stated that the process of program budgeting needs to be based on program that must to be given by the working unit, and provide a budget in the form of a program that is supported by cost and performance information. The next step is that the DPPAPP will participate in forums that will discuss further steps of the planning and budgeting process, until it can be legitimized and executed.

The process of drafting the DPPAPP is the responsibility of all elements within the DPPAPP. However, the subsector of planning dan budgeting have a much higher workload in the drafting and budgeting process. The high amount of responsibility, requires good human resources, both quantitywise as well as quality-wise. According to [26], in order to reach the focus of organization, good quality and quantity of human resources is needed. Such human resources constitute of good quality, but from the observation that is done by the researchers from the planning, quantity is still lacking, after confirming to 1 key informant.

\section{B. Budget Execution}

Budget execution is a phase that has been done since the APBD that has been legalized via the usage of peraturan daerah every end of the year before the new budget is done. The phase started from the one year that the new budget plan started, which starts in January every year. The proses that started when the budget is done via the DPPAPP is the creation of the Document of Budget Execution or DPA in Indonesia. After the document is done, then the subsector of finance will give the document towards the PPKD to be legalized. Then, after the document is legalized the programme will start. The total budget of DPPAPP at the start of APBD year 2019 is Rp. 550.783.932.265.

However, to ensure that the work will be done, every subsector will make a TOR. The TOR will contain: Date of the work, output of the work, place of the work, and the goal of the work. After making the TOR, then the TOR will be given towards the head of department to be evaluated and checked upon. APBD will be divided into 2 semesters; which are the first and second semester. After the first semester of the budget is used, then there shall be a complete evaluation 
regarding the budgeting. After the evaluation is done, then the APBD will change into APBD-P. It refers to the revamp of the APBD. The APBD-P can either go upwards or downwards. APBD-P can only be done once in regard to the period budget itself. APBD-P starts in the month of October. Then, the evaluation of the first semester of the budget is done, and thus further document is needed to be prepared. Such document is Document for the Placement of Budget Changes (DPPA). DPPA is used for the replacement of DPA, especially if there is such activities or budget that is changes, both rising, downwards or the placement of additional activities.

\section{Problem in the process of Budget Planning and Budget Execution}

The DPAPP have various problems in terms of planning as well as execution of the budget. In the process of budget drafting, the first problem is the fact that the process is quite slow. Formulation and changes happen constantly, and thus the progress of work seems to be non-existent. In terms of inserting the data towards the system of E-Budgeting, problems arise however it still could be solved with the DPPAPP. The system that can be opened or closed anytime, even outside of the working hours. As such, the versatile of the data input is very important.

Further problems that are experienced by the DPPAPP is the fact that the execution of the budget is quite troubling. Numerous dependences on the outside party, further to be called the third party is the fact that they have problems, and as such need consultation and more time to finish such work, hampering the work themselves. When such persons cannot attend the event for various reason, and they are indeed very important due to the scope of the work, it will cause troubles. Especially due to the fact that there are no alternatives, and as such it has to be rescheduled, further hampering the work itself.

\section{Factor Regarding the Inconsistency between the Planning and the Execution of the Budget}

Inconsistency can be defined as when the end result is not what is expected before. Inconsistency in this realm is the DPPAPP, which is the government institution that does the project or the budget is not fulfilling the expectation that has been discussed before. Inconsistency can result in such a budget to be nonoptimal As explained by [27], the absorption of the budgeting of the work is proportional to the budget that has been realized in one year.

Condition of the absorption that is low and unproportioned, according to [24] will affect towards :

a. Overall slowness of the execution of government programme and will affect the public sector.

b. The delay of the disbursement of funds to buy good/sector that will result in the reduction of stimulus fiscal and the multiplier effect from the purchase of the government towards the reduction of economic impacts as a whole, especially in the start of the budgeting year.

c. Increasing amount of debt towards states at the end of the year, causing more pressure towards the provision of the government cash, resulting in possible cash mismatch As thus, government institutions will need to ensure that the budget as well as the events are done based on the planning that have been made before, to ensure the maximum usage of the budget.

TABLE I: DPPAPP BUDGET REALIZATION

\begin{tabular}{ccccc}
\multicolumn{5}{c}{ TABLE I: DPPAPP BUDGET REALIZATION } \\
\hline No & $\begin{array}{c}\text { Type of } \\
\text { Expenditure }\end{array}$ & $\begin{array}{c}\text { Budget Change } \\
(\text { Rp) }\end{array}$ & $\begin{array}{c}\text { Realization } \\
(\text { Rp) }\end{array}$ & $\begin{array}{c}\text { Realization } \\
(\%)\end{array}$ \\
\hline \multirow{2}{*}{1} & $\begin{array}{c}\text { Indirect } \\
\text { Expenditure } \\
\text { Direct }\end{array}$ & 218.435 .256 .000 & 212.415 .543 .241 & 97,24 \\
2 & $\begin{array}{c}\text { Dxpenditure } \\
\text { Total }\end{array}$ & 507.421 .053 .853 & 294.407 .821 .577 & 95,77 \\
& & 525.856 .309 .853 & 506.823 .364 .818 & 96,38 \\
\hline
\end{tabular}

According to the observation that is done by the researched, it could been from the realisation of the budget that there is part of the budget that is not absorbed by the DPPAPP. According to [15], it could be proves that the stimulant of budgeting factor and planning, implementation of budgeting internal united, human resources, document and administration, influence the budget absorption $t$ the end of the year, however the factor of human resources and factor that influence the absorption of budgeting at the end of the year. According to [10], [29] budget failure is due to the mismatch at both internal and external factors. As thus, inconsistency between the implementation of budget have made the end result not optimized well. Especially, the DPAPP has maintained a reducal of qualities, in regards with the following factors:

\section{Internal Factor}

Internal factors indeed could influence the inconsistency of DPPAPP in terms of planning as well as execution, which is the human resources. According to [37], factors that contribute towards the slowness of the realisation of the budgeting absorbency is influenced by the quality of the human resources that is lacking. The lack of human resources that is found in DPPAPP in furious factor, for example in the drafting of the event as well as implementation of the budget could contribute towards the inconsistency and the absorption of the budget. Thus, in terms of the execution of such events, the human resources or the fields are still faced with various issues. Furthermore, the event as well as the execution is lacking as a whole. This research have various similarities with the various research that has been done by [35], which in his research also concur that the human resources is still very lacking, especially in terms of overall knowledge in finance management. According to [6], every part of the human resources is important towards the aim of the organization to achieve their goals. In accordance, Aswar and Ermawati [6] believes that human resource sis one of the biggest problem in terms of achieving the system

\section{External Factors}

External factors that could contribute towards the overall inconsistency between the planning as well as the execution of the budgeting at DPPAPP happens because of various reasons. The first one is the fact of auction for the procurement of goods. This is highly important due to the fact that this is done to ensure the needs of the people is done in the public sector [8]. In accordance with [30], the auction has to be done by DPPAPP, especially if the amount of purchase will exceed 200 million. However, the process of the auction cannot be predicted with how long the total time will take. Due to this uncertainty, DPAPP constantly faces various recklessness in terms of time management. Thus, this recklessness causes the total budget to be much bigger at the 
end of the period. This research concerned with the research that is done by [4]. He believes that the process of auction is filled with various problems in terms of the tender process, which will cause further problems and adding problems for the realisation of the budgeting itself.

The next problem is still in the realms of auction. In terms of the observation that is done by the research team, DPPAPP frequently faces inconsistency in terms of planning and execution of the budget due to the fact that the various programmes are added after the budgeting is done. For instance, DPPAPP has planned or stated the budget is 1 billion for the purchase of KB cars. To ensure the purchasing of the item, an auction is needed to be done. At the end of the auction, the company that won the bid auctioned for a total of 750 million. Due to the advantages, such a company will be chosen and therefore the price difference will cause trouble in the budgeting, with the amount of price below the standard.

The final external factor is the change of regulation that is done by the local government of DKI Jakarta. In accordance to theory, according to [8], in terms of organization management, regulation must be respected. Thus, it could be said that DPAPP is needed by the local government of DKI Jakarta to ensure the efficiency of such a budget, and DPAPP have to follow the regulation that concedes. This is supported by the research that is done by [33] that states that regulation is a factor that will contribute towards the realisation of the budget. Thus, problems arise when some sector of the budget is not absorbed, mainly for the activities for the accompaniment planning as well as budgeting of gender responsive and the event of the increasement of woman institution network and child in accordance to the quality of children and women. Those two activities is regarded as efficient due to the regulation set by the government of DKI Jakarta.

"I believe that, in my most humbleness opinion, sub sector of budgeting is one of the hardest sector, due to the amount of work that is provided. To add, planning of the budgeting takes quite a long time, around 1 year. That is merely the planning phase, not the execution and the other process. As thus, the human resources is quite lacking due to the amount of work that is needed." (Manuscripts: KI.2, Interview 20 December 2019)

The orders will then be given towards the head of SKPD, which will then be ordered to be done as efficiently as possible. For the work plan of PPRG, that is once formulated to be 3 activities, but then the budget can only be efficiently given towards 1 people. However, with the efficiency that is done, it does not mean that the PPA, which acts as the guarantor, does not do any work, but said work will be done, even if it has to be done without such budget. For the activities of the increasement of woman institution network and child.

\section{CONCLUSION, LimitATIONS AND RECOMMENDATIONS}

This study focuses to identify the planning as well as execution for the budget of PPAPP as well as understanding its problem- mainly in terms of failure in the planning phase and the budgeting as a whole, which produces further inconsistency, between the planning as well as the realisation phase. This research is done through the method of interview as well as the approach of ethnomethodology. Thus, it could be concluded in regards towards the actions which contribute to the budgeting, as well as its problem. While indeed DPPAPP has been regarded with the procedure that is applicable- mainly Law Number 25 Year 2004 with the phase of the drafting of the budget, RKPD, KUA, PPAS, RKASKPD and APBD.

However, the human resources in the sub sector of planning, still possesses weakness in terms of the working forces, and further steps must be done, through possible help with the sector of finance to ensure the betterment of the DPPAPP. Next, although DPPAPP has done the planning phase in accordance to the procedure that has existed, it cannot be denied that problems exist, mainly in terms of planning and execution. In addition, human resources quality needed to be enhanced, as there is still various misunderstanding in terms of understanding as well as ability as a whole.

Those factors contribute towards the inconsistency between the planning as well as the realisation of the budgeting. Various events that are supposedly held are not done, due to negligence. Externally, revision and revamp are needed as a whole. The auction system has to be changed, otherwise problems will always exist.

\section{REFERENCES}

[1]. Ahmadi, R. (2014). Metodologi Penelitian Kualitatif. Ar-Ruzz Media.

[2]. Akbar, R., Pilcher, R. and Perrin, B. (2015). Implementing Performance Measurement Systems : Indonesian Local Government under Pressure. Qualitative Research in Accounting \& Management. https://doi.org/https://doi.org/10.1108/

[3]. Andre P. Tulangow, T. R. (2016). Analisis Realisasi Anggaran Pendapatan dan Belanja Daerah Pemerintah Kabupaten Minahasa. Jurnal EMBA, 4(3), 564-571.

[4]. Arif (2012). Akuntansi Pemerintahan. Jakarta : Salemba Empat.

[5]. Aswar, K., \& Ermwati, E. (2019). Pengadopsian akuntansi akrual di pemerintah daerah: Studi kasus pada provinsi Banten. Equity, 12 (1), 62 74 .

[6]. Aswar, K., \& Saidin, S. Z. (2018). Accrual accounting adoption in Java municipalities: An empirical investigation. International Joural of Business and Economic Sciences Applied Research, 11 (3), 24-30.

[7]. Basri, Ramlah. 2013. Analisis Penyusunan Anggaran Dan Laporan Realisasi Anggaran Pada BPM-PD Provinsi Sulawesi Utara. Skripsi. Universitas Samratulangi. Manado. Jurnal EMBA. Vol.1 No.4. (2013).

[8]. Bastian, Indra. (2010). Akuntansi Sektor Publik Suatu Pengantar Edisi Ketiga. Penerbit Erlangga :Jakarta

[9]. Bastian, Indra. (2006). Sistem Akuntansi Sektor Publik, Edisi 2, Jakarta: Salemba Empat.

[10]. Basyir, A. (2015). Faktor-Faktor Yang Mempengaruhi Realisasi Anggaran Belanja Pendidikan Di Provinsi Aceh. Jurnal Ilmu Ekonomi, $3(1)$.

[11]. BPKP. (2011) Menyoal Penyerapan Anggaran. Yogyakarta: Paris Review.

[12]. Creswell W. John. (2013). Research Design Pendekatan Kualitatif, Kuantitatif, dan Mixed. Yogyakarta : Pustaka Pelajar

[13]. Dadan Rahmadani, I. Z. A. (2017). Pengaruh Perencanaan Anggaran,Kualitas Sumber Daya Manusia Dan Pelaksanaan Anggaran. Jurnal Riser Akuntansi, 10(1), 134-148.

[14]. Efferin Sujoko, Darmadji Hadi Stevanus, Tan Yuliawati, (2012). Metode Peneltian Akuntansi, Yogyakarta, Graha Ilmu

[15]. Fitriany, N., GN. Masdjojo, \& T. Suwarti. (2015). Exploring The Factors that Impact The Accumulation of Budget Absorption in The End of The Fiscal Year 2013 : A Case Study in Pekalongan City of Central Java Indonesia. South East Asia Journal of Contemporary Business, Economics and Law. Vol.7, Issue 3 (Aug) ISSN 2289-1560

[16]. Jensen, M., C., dan W. Meckling, (1976). "Theory of the firm: Managerial behavior, agency cost and ownership structure", Journal of Finance Economic 3:305- 360.

[17]. Jovan Febriantoko, F. (2017). Proses Penyusunan Dokumen Perencanaan Dan Laporan Pertanggung Jawaban Pemerintah Daerah Di Indonesia: Pendekatan Kualitatif. 12(2), 143-155. 
https://doi.org/10.21107

[18]. Kamayanti, Ari. 2016. Metodologi Penelitian Kualitatif Akuntansi: Pengantar Religiositas Keilmuan. Penerbit : Yayasan Rumah Peneleh, Jakarta Selatan

[19]. Korompot, Rizka.dkk (2015). Analisa Penyusunan Anggaran pada Dinas Pendapatan Pengelolaan Keuangan dan Aset Daerah Kota Kotamobagu Tahun Anggaran 2014. Tesis Magister. Manado, Universitas Sam Ratulangi

[20]. Lupia, A. and McCubbins, M. (2000). Representation or abdication? How citizens use institutions to help delegation succeed. European Journal of Political Research 37:291-307.

[21]. Mardiasmo. (2018). Akuntansi Sektor Publik (edisi terb). Andi.

[22]. Mauro, Sara Giovanna. 2019. Public Sector Performance-Based Budgeting in Italy. In Performance-Based Budgeting in the Public Sector. Edited by Michiel S. de Vries, Juraj Nemec and David Špacek. Basingtoke: Palgrave Macmillan, pp. 125-40.

[23]. Miles, M.B, Huberman, A.M, \& Saldana, J. (2014). Qualitative Data Analysis, A Methods Sourcebook, Edition 3. USA: Sage Publications. Terjemahan Tjetjep Rohindi Rohidi, UI-Press.

[24]. Miliasih, Retno. (2012). Analisis Keterlambatan Penyerapan Anggaran Belanja Satuan Kerja Kementerian/Lembaga TA 2010 di Wilayah Pembayaran KPPN Pekanbaru. Tesis. Universitas Indonesia : Jakarta.

[25]. Moleong, Lexy J. (2010), Metodologi penelitian kualitatif, Remaja Rosdakarya,Bandung.

[26]. Nahidah. (2016). Analisis perencanaan rekrutmen Aparatur Sipil Negara Kabupaten Mamuju Utara. E Jurnal Katalogis, 4(5), 87-97.

[27]. Noviwijaya, A \& A. Rohman (2013). Pengaruh Keragaman Gender dan Usia Pejabat Perbendaharaan terhadap Penyerapan Anggaran Satuan Kerja (Studi Empiris pada Satuan Kerja Lingkup Pembayaran KPPN Semarang I). Diponegoro Journal of Accounting, 2(3).

[28]. Oman Rusmana, Dyah Setyaningrum, Yuliansyah, M. (2017). Akuntansi Pemerintah Daerah. Jakarta Selatan: Salemba Empat.

[29]. Pangkey, I., \& Pinatik, S. (2015). Analisis Efektifitas dan Efisiensi Anggaran Belanja. Jurnal EMBA, 3(4), 33-43.

[30]. Peraturan Presiden Republik Indonesia Nomor 4 Tahun 2015 Tentang Perubahan Keempat atas Peraturan Presiden Nomor 54 Tahun 2010 Tentang Pengadaan Barang/Jasa Pemerintah., Pub. L. No. NOMOR 4 TAHUN 2015, 53287 (2015).

[31]. Prowle, Malcolm. (2014). The role of budgeting systems in supporting strategic management in the public sector. In Developments in Strategic and Public Management: Studies in the US and Europe, 1st ed. Edited by Paul Joyce, John Bryson and Marc Holzer. Basingstoke: Palgrave Macmillan, pp. 21-40

[32]. Ramlah Basri. (2013). Analisis Penyusunan Anggaran dan Laporan Realisasi Anggaran pada BPM-PD Provinsi Sulawesi Utara. 1(13), 202-212.

[33]. Rifka Ramadhani, M. A. S. (2019). Pengaruh regulasi, politik anggaran, perencanaan anggaran, sumber daya manusia dan pengadaan barang/ jasa terhadap penyerapan anggaran belanja pada opd provinsi sumatera barat. Jurnal Eksplorasi Akuntansi, 1(2), 710-726.

[34]. Robinson, Marc and D. Last. (2009). A Basic Model of PerformanceBased Budgeting. Technical Notes and Manuals. International Monetary Fund. Washington.

[35]. Rustam. (2016). Analisis Proses Perencanaan Dan Pelaksanaan Anggaran. Jurnal Katalogis, 4(5), 209-216.

[36]. Undang-Undang Republik Indonesia Nomor 25 Tahun 2004 Tentang Sistem Perencanaan Pembangunan Nasional Dengan Rahmat Tuhan Yang Maha Esa Presiden., Pub. L. No. Nomor 25 Tahun 2004, 32 (2004).

[37]. Widianingrum, D., Kustono, A. S., \& Suryaningsih, I. B. (2017). FaktorFaktor Yang Memengaruhi Penyerapan Anggaran Satuan Kerja Perangkat Daerah Di Pemerintah Kabupaten Situbondo. Bisma, 11(2), 194. https://doi.org/10.19184/bisma.v11i2.6314. 